\title{
Latviešu profesionālās apvienības trimdā: jūrniecības nozares piemērs
}

\author{
Latvian Professional Associations in Exile: The Example \\ of Maritime Industry
}

\author{
Dāvis Beitlers, Mg. hist. \\ Latvijas Universitātes doktorants \\ Rīgas vēstures un kuğ́niecības muzeja vēsturnieks \\ Palasta iela 4, Rīga, LV-1050 \\ E-pasts:davis.beitlers@tvnet.Iv
}

Rakstā sniegts neliels ieskats latviešu trimdas saimniecisko darbinieku kooperatīvajā sistēmā, tuvāk apskatot latviešu jūrniecības darbinieku (jūrnieku, kug̣īpašnieku) kooperēšanās un biedrošanās centienus, kas, lai gan vainagojās minimāliem panākumiem, tomēr liecina par dažām parādībām latviešu trimdas dzīvē, kuras saistās tiklab ar Rietumvalstu saimnieciskajām tendencēm, kā latviešu mentalitātes īpatnībām.

Atslēgvārdi: latviešu trimda, kuğniecība, profesionālās organizācijas, Latvijas Republikas diplomātiskās pārstāvniecības Rietumos.

The article provides a brief insight into the cooperative system of the Latvian exiles' economic workers, with a closer look at the efforts of Latvian maritime workers (sailors, shipowners) to cooperate and form associations, which, although scarcely successful, nevertheless shows some phenomena in the Latvian exile life, which are related to the economic trends of Western countries, as well as the specific characteristics of Latvian mentality.

Keywords: Latvian exile, shipping, trade unions, business, diplomatic missions of the Republic of Latvia in the West.

Latviešu biedrošanās tieksme, kas uzdīga 19. gadsimtā un skaitliski kulminējās starpkaru posmā, lielā mērā saglabājās arī trimdā pēc Otrā pasaules kara. Jau sākot ar trimdas rītausmas gadiem, "brīvajā pasaulē" nonākušie latvieši sāka veidot gan reǵionālās, gan nozaru politiskās, kultūras un saimnieciskās - struktūras, proti, nevalstiskās organizācijas ārpus mītnes valstu un Latvijas diplomātisko pārstāvniecību jurisdikcijas. Par daudzām reǵionālajām, sabiedriski politiskajām un kultūras biedrībām un apvienībām Latvijas historiogrāfijā, ieskaitot atmiņu-memuāru literatūru un informatīvus izdevumus, 
rakstīts samērā daudz, taču aplam maz vēstìts par Latvijas izcelsmes profesionāḷ un saimniecisko darbinieku trimdā veidotajām kooperācijām un mēǵinājumiem tās uzsākt. Vēl jānoskaidro, cik plaša bija šī kooperācija un kāda bija kopdarbības nozīme trimdinieku profesionālajā dzīvē.

Domājams, vismaz trimdas sākumgados kooperatīvā aizmugure ne vienam vien svešuma latvietim varēja būt izškiirīga, meklējot nozarei atbilstošu darbu: ne vienmēr latviešiem, kas vēlējās darboties noteiktā nozarē, bija iespējams raiti iekḷauties mītnes zemes profesionālajā sabiedrībā - nācās paciest gan to, ka bēg̣̣u aprūpes struktūras, kam pienācās sekmēt baltiešu emigrantu nodarbinātību Rietumvalstu uznēemumos, nebija uzdevumu augstumos, gan vietējo arodorganizāciju pretestību darbvietu deficīta gadījumā. ${ }^{1}$ Dažas no pirmajām trimdā organizētajām arodstruktūrām, kas darbojās pārvietoto personu ${ }^{2}$ nometnēs Vācijā un tika uzskatītas par starpkaru un karalaika ${ }^{3}$ Latvijas arodstruktūru tiešu turpinājumu, ne tikai tiecās risināt trimdinieku nodarbinātības un, varētu teikt, arī kvalifikācijas celšanas pamatproblēmas attiecīgajās mītnes zemēs (Vācijā un Austrijā); vērojami arī centieni sakārtot bēgḷu nometñu gados vērojamo amatlietu jucekli pašu tautiešu kopienā, novelkot iekšejās robežas. 1945. gada nogalē izveidotā Latviešu preses biedrība retoriskā līmenī pūlējās reglamentēt, piemēram, to, cik latviešu preses izdevumu pielaujams izdot uz noteiktu skaitu bēgḷ nometņu un cik lielā mērā šie izdevumi drīkst būt ideologiski atkarīgi no dažādām Rietumvalstu struktūru interesēm. ${ }^{4}$ Šajā aspektā zināmā mērā vērojamas prioritāšu atškirīibas, salīdzinot līdzīgas latviešu trimdas arodstruktūras Vācijā un Zviedrijā: Vācijā, kur pēckara gados valdīja sabiedrotie un darbojās vairākas bēg̣̣u aprūpes struktūras, darbs vai iztika daudziem trimdiniekiem vismaz uz laiku jau bija nodrošināta un latvieši varēja sākt apspriest konceptuālas kopienas un identitātes problēmas pragmatisko pamatvajadzību risināšanas vietā, taču Zviedrijā tas bija vēl priekšā. Protams, "siltumnīcas laikam" DP nometnēs beidzoties un sākoties izklīšanai pa visu "brīvo pasauli", darba un iztikas meklējumi apsēda arī bijušo Vācijas nometnieku prātus un tikai pieauga vajadzība pēc šādām arodstruktūrām arī ārpus Zviedrijas. Trimdas vēlākajās desmitgadēs, spītējot izkliedētībai, latvisko arodstruktūru loma, škiet, mazliet mainījās: tagad tās noderēja pirmām kārtām par zināmu domu apmaiņas forumu zem vienas profesionālās kores apvienotām latviešu trimdinieku kopām, sapulcēs un kongresos nereti apspriežot arī atjaunojamās Latvijas tautsaimniecības nozares atjaunotni un tās priekšdarbus trimdā.

Latviešu trimdas profesionālās kooperācijas svarīgāko struktūru sarakstos rindojas tiklab kultūras druvas kopēju, kā arī ārstu, ${ }^{5}$ mežkopju, ${ }^{6}$ juristu, ${ }^{7}$ inženieru, ${ }^{8}$ dzelzceḷa ierēdṇu $^{9}$ un citas biedrības, kopas un apvienības, kā arī vairākas plašas dažādu nozaru latviešu saimniecisko darbinieku apvienības Vācijā (bēgḷu nometņu laikā), ASV un Kanādā; to veidotāji jau pašos pirmajos trimdas gados apzinājās, ka "turpmākās gaitas [svešumā no latviešu uznēēējiem D. B.] prasīs lielāku saimniecisku patstāvību un kooperatīvais sadarbỉbas ceľ̦s garantēs vislabākās sekmes", un tālab "ar kāpinātu sparu [...] latviešu saimei jāpopularizē kooperācijas izpratne un jāpanāk ciešāka dažādo kooperativo pasākumu sadarbïba". ${ }^{10,11}$ Diemžēl šajā rosmīgajā trimdas vēstures lappusē tikai epizodiski pavīd kādas Latvijai vēsturiski un arī latviešu trimdas kopienā gana būtiskas tautsaimniecības nozares - jūrniecības - darbinieku biedrošanās centieni, kas ne reizi garajos svešuma gados nav vainagojušies redzamiem panākumiem un noturīgiem rezultātiem. Nelīdzēja arī tas, ka jau kopš pirmajiem baltiešu trimdas gadiem latviešu sabiedrībai teju acu 
priekšā bija veiksmīgs piemērs, kā šīs lietas kārtojamas, - tā bija kaimiṇtautas igauṇu jūrnieku kooperācija, kas vienoja igauṇu cilmes jūrniecības darbiniekus gandrīz vai visā Rietumu pasaulē.

Jau tūlīt pēc kara, 1945. gadā, Stokholmā darbu uzsāka Igauṇu jūrnieku biedrība ar 550 biedriem, ${ }^{12}$ savukārt 1955 . gada sākumā nodibināta vēl plašāka struktūra Igauṇu jūrnieku arodbiedrība, ${ }^{13}$ kas tiecās apvienot igauṇu jūrniekus praktiski visās "brīvās pasaules" valstīs un 1956. gadā uzṇemta Starptautiskajā Transporta federācijā, kḷūstot par pirmo un vismaz vairākus gadus arī vienīgo baltiešu trimdas arodorganizāciju, kura uzṇemta starptautiskās profesionālajās struktūrās. ${ }^{14}$ Igauṇu jūrniecības arodstruktūrām bija būtiska nozīme igauņu cilmes jūrnieku nodarbinātības veicināšanā trimdā: pirmkārt, tās palīdzēja igauṇu jūrniekiem iekārtoties darbā Rietumvalstu kuǵniecības struktūrās (par to igauṇu jūrnieki lielā mērā bija parūpējušies jau starpkaru laikā, sekmīgi meklējot kontaktus Zviedru jūrnieku apvienībā un tādā kārtā saviem tautas un amata brāliem nodrošinot gan panākumus darba meklējumos, gan uzticamību un atpazīstamību arī trimdas posmā Rietumos); otrkārt, panāca, ka daudzi igauņu izcelsmes kuǵīpašnieki Rietumos - un tādu igauniem trimdā bija krietni vairāk nekā latviešiem - uzņemas rūpes par tautiešu nodarbināšanu, priekšroku darba meklētāju pulkā dodot nevis sveštautietim vai jebkuram gribētājam neatkarīgi no nacionālās piederības, bet gan tieši igauṇu jūrniekam. Ne reizi vien Igauņu jūrnieku arodbiedrības darbība nāca par labu arī šai ziṇā mazāk izdarīgajiem un uzṇēmīgajiem dienvidu kaimiņiem. ${ }^{15}$ Tomēr ne jau vienmēr kaimiņam klāt izstāvēsi, un dažs labs patiesi neveiksmīgs piemērs liecina, cik svētīga būtu pašu latviešu jūrniecības darbinieku apvienošanās trimdā (pat ja latvieši nevarēja lepoties ar tik lielu rēderu skaitu trimdā kā igauṇi). Viens no zināmākajiem gadījumiem, kura sekas, iespējams, jau saknē būtu spējusi novērst veikla un tālredzīga latviešu jūrnieku arodbiedrības rīcība (ja vien šāda arodbiedrība pastāvētu) pēc konkrētiem igauṇu piemēriem, ir latviešu cilmes kugịipašnieka Viḷna Grauda (dz. 1923) negodīgā rīcība pret latviešu jūrniekiem Vācijas bēgḷu nometnēs - viṇiem pēdējā brīdī tika atteiktas darbvietas uz Graudu rēderejas kug̣a, lai gan tās šis latviešu cilmes amerikāṇu kuǵīpašnieks saviem tautiešiem bija apsolijjis nodrošināt. ${ }^{16}$

Zīmīgi, ka jūrnieka arods trimdas apstākḷos bija viens no pašiem nepastāvīgākajiem un neparedzamākajiem visu saimniecisko nodarbošanos spektrā; šāds jūrnieks, kādu latviešu vidū pēckara Rietumvalstīs bija ap tūkstoti, varēja kḷūt sociāli tik neaizsargāts, ka stingra un uzticama sociāli juridiskā aizmugure noteiktas kooperatīvas arodstruktūras izskatā būtu bijusi ne tikai vēlama, bet drīzāk (vismaz trimdas sākumposmā) - vitāli nepieciešama. Turpmāk minētas tikai dažas problēmas, kuras kā Damokla zobens svešumā karājās pār daudzu latviešu jūrnieku galvām: nodarbinātība svešu valstu dienestā, pastāvot riskam reisu laikā piestāt Padomju Savienībai draudzīgās valstīs vai pat tieši "plašajā Dzimtenē", ${ }^{17}$ neparedzamas izmaiñas kuğa un tā apkalpes juridiskajā piederībā, ārzemju valodu neprasme, problēmas sanemt mītnes zemes pilsonību un uzturēšanās ațaujas, kas bieži traucēja gan iegūt darbu uz kugiem, gan izkāpt krastā valstīs, kuru ostās kug̣is piestāja (nereti jūrnieki bez vajadzīgajiem dokumentiem nonāca krastu dienestu īslaicīgā apcietinājumā, kamēr pārējie varēja brīvi baudīt atpūtas mirkḷus krastā), pat politiski ideologiski aizspriedumi pret latviešu kuǵiniekiem kā komunistu aǵentiem $^{18}$ u. tml. ${ }^{19}$ Daudziem latviešu jūrniekiem trimdiniekiem atškirībā no vairuma sauszemē nodarbināto latviešu klaidnieku ilgstoši trūka pastāvīgas dzīvesvietas, un 
daḷai no viņiem tādas nebija vēl 50. gadu vidū, jādomā, arī vēlāk ne. Klaidā nonācis jūrnieks, gadiem šūpodamies jūrā un tikai īslaicīgi izkāpdams krastā, varēja arī nebūt pastāvīgi noenkurojies - iekopis mājvietu, nodibinājis gimeni. To nereti kavēja ne vien jūrnieka aroda specifika, bet tieši minētās problēmas iegūt uzturēšanās atḷauju un pilsonību, jo, saprotams, ne katrā zemē bija iespējams apmesties bez šiem papīriem, vai arī iegūt vajadzīgos dokumentus bija ārkārtīgi sarežgìiti - îpaši bez pastāvīgas dzivesvietas uz sauszemes. Nav grūti iedomāties, cik nepatīkama un pat bīstama pastāvīgas dzīvesvietas trūkuma dēḷ šādam latviešu jūrniekam varēja izrādīties darba attiecību pēkšņa izbeigšana ar kāda ārzemju kuǵa saimnieku vai atbrīvošana no darba kaut uz nenoteiktu laiku (ja ne pavisam) un "aizsūtīšana mājās". Tāpat jūrnieka ilgstošā atrašanās jūrā sveštautiešu vidū kug̣u apkalpēs un epizodiskā uzturēšanās krastā nozīmēja arī pastāvīgu prombūtni no sava tautiešu loka. No šì apburtā ap̣̣a varēja izrauties, vienīgi izpelnoties mītnes valsts pavalstniecību, kuras iegūšana pavēra ceḷu uz Rietumos atzìtas jūrniecības izglītību un stabilākiem darba apstākḷiem ar pilsoṇvalsts politiski saimniecisko aizmuguri. ${ }^{20}$

Cits problēmu loks samezgloja latviešu rēderu dzīvi un darbību svešumā. Protams, vairumā gadījumu šie uzṇēmēji vai agrāko uzṇēmēju - starpkaru Latvijas kuǵīpašnieku - mantinieki nebūt nebija tik sociāli neaizsargāti kā ierindas jūrasbraucēji, tomēr arī viņus trimdas ceḷos piemeklēja ne viens vien smags problēmjautājums. Vajadzēja prast aizstāvēt savas intereses lielvalstu saimnieciskajā arēnā, veikli iekḷauties mìtnes valsts saimnieciskajās struktūrās un Rietumu pasaules tautsaimniecībā kopumā, izprast tās principus. Šḳiet, tas izdevās tikai vienam no latviešu kuǵîipašniekiem jau pieminētajam V. Graudam, starpkaru laika Latvijas kuǵniecības magnāta Friča Grauda (1888-1942) dēlam, kura uzṇēmums trimdā darbojās vairāk nekā 20 gadu. $^{21}$ Daudz sliktāk klājās, piemēram, starpkaru Latvijas gados tik veiksmīgajam kug̣īpašniekiem Jānim Zalcmanim (1887-1971) ASV, kura rēdereja, Beḷgijā reg̣istrētā Latvijas kuǵniecības sabiedrība (Latvian Shipping Company), pēc dažu gadu darbības 50. gadu otrajā pusē bankrotēja ${ }^{22}$ (izskatās, ka tuvu tam bija arī Artura Zēberga (1888-1964) rēdereja Anglijā, ${ }^{23}$ tā darbojās teju vienā laikā ar J. Zalcmaṇa uzṇēmumu - abas izveidotas 1955. gadā, abas darbojās dažus gadus līdz 50. gadu beigām - 60. gadu sākumam). Pavisam konkrētu traucēkḷ sarakstā priekšplānā izvirzās latviešu kuǵīpašnieku reizumis visai smagā cīṇa par savu kuǵniecības īpašumu atgūšanu pēc tam, kad tos Otrā pasaules kara gados bija ekspluatējuši Rietumu lielvalstu kara resori. ${ }^{24}$ Kompensāciju izmaksa par karalaikā bojāgājušajiem Latvijas pavalstnieku kug̣iem saistijjās ar virkni strīdīgu tiesisko problēmu (piemēram, par pretinieka vainu kuğu nogremdēšanā iepretim ekspluatētāju bezatbildībai, kug̣us sūtot tieši ūdens mīnu laukos), jo, lieki piebilst, - maksāt nevēlējās neviens. Lai panāktu savu, kā ASV, tā Lielbritānijas dienestā nogremdēto kug̛u ìpašniekiem nācās mēroties juridiskajā veiklībā ar lielvalstu varas iestāžu pārstāvjiem. Bija jāalgo dārgi advokāti un izmanīgi juridiskie konsultanti, jāveic gūzma dažādu procedūru valsts struktūrās - kooperējoties tas droši vien būtu vieglāk paveicams uzdevums.

Kā redzams, latviešu jūrniecības darbinieku - kā jūrasbraucēju, tā kug̣u turētāju - saimnieciskai kooperācijai iemeslu patiesi netrūka - nedz trimdas sākumgados, nedz arī vēlākās desmitgadēs. To trūkumu nespēja kompensēt arī starptautiskās organizācijas un struktūras, kas nodarbojās ar attiecīgajiem jautājumiem. Te var minēt kaut vai ANO struktūras, kuru spēkos bija palīdzēt latviešu jūrniekam tikai atseviškāās situācijās - piemēram, smagu veselības 
problēmu gadījumā, kas padarītu neiespējamu kuğošanu; citās neveiksmēs jūrnieks varēja cerēt vienīgi uz attiecīgo valstu amatpersonām un Latvijas Republikas pārstāvniecību atbalstu, kas arī ne vienmēr nesa cerēto. ${ }^{25}$ Par veiksmīgu nevarētu uzskatīt arī Starptautiskās Bēgḷu aprūpes organizācijas (IRO - International Refugee Organisation ${ }^{26}$ iesaistīšanos latviešu jūrlietās, un tā nebija pārāk aktīva arī latviešu bēgḷu aprūpē kopumā, iesaistoties šai darbā vien 1948. gadā;27 šîs struktūras sniegto atbalstu visai zemu vērtēja arī pašās latviešu bēgḷu jūrnieku aprindās, un jau bēg̣̣u nometṇu laika nogalē izskanēja pārmetumi, ka "par DP jūrniekiem IRO lìdz šim maz interesējusies". ${ }^{28}$ Pavisam konkrēts šādas nespēcības piemērs ir IRO rīcībā nodotā kuǵa Skaugum gadījums, kad šī organizācija nejaudāja aizstāvēt bēg̣̣u intereses, piel̦aujot, ka Norvēg̣ijas jūrnieku arodbiedrības spiediena dēḷ latvieši zaudē apsolītās darbvietas uz minētā norvēǵu tvaikon, ${ }^{29}$ Tāpat latviešu jūrniekiem, iespējams, informācijas trūkuma dēl, ${ }^{30}$ vismaz līdz 50. gadu beigām un 60. gadu sākumam nebija izveidojusies gana cieša sadarbība ar vietējām latviešu kopienām un to organizatoriskajām struktūrām - biedrībām ${ }^{31}$ un relig̣iskajām draudzēm. ${ }^{32}$ Kā zināms, tieši vietējās latviešu draudzes un reliǵiskās kopienas bija tās struktūras, kas nereti uzturēja ar tautiešu jūrniekiem ciešus sakarus, morāli vai pat materiāli atvieglojot jūrnieku uzturēšanos vienā vai citā tālā zemē un ostā. ${ }^{33}$ Pēc Otrā pasaules kara, kad latviešu jūrnieku skaits "brīvajā pasaulē" bija krietni pieaudzis, šī tendence vairs nebija tik izteikta, tomēr pavisam nenoplaka.

Par spīti spilgtajai igauņu priekšzìmei un daudzajiem apstākḷiem, kas tieši vai netieši ${ }^{34}$ rosināja un veicināja kooperatīvo struktūru izveidi, kā jau minēts, latviešu trimdas jūrniecības darbinieku biedrošanās tieksme bija visumā remdena un zināma dedzība uzvirmoja tikai atsevišḳu indivīdu nodomos, kas gan tika manifestēti, bet plašu jūrnieku sabiedrības atsaucību neguva. Šie mēǵinājumi un epizodiskās ieceres, kādas tātad tomēr varam ieraudzīt, saistās gan ar trimdas sākumgadiem, gan vēlāku laikposmu. Atšķirība starp abiem laikposmiem iezīmējas neatkarīgas Latvijas atjaunotnes idejas intensitātē un no tās izrietošajā pārliecībā par trimdas stāvokḷa ilgumu jeb ilgstamību - īslaicīgumu vai, gluži pretēji, ilglaicīgumu. Vismaz līdz 40. gadu beigām daudzi baltiešu trimdinieki šo svešuma lāstu uzskatīja par pagaidu stāvokli, bet no 50. gadu sākuma, kā zināms, šādas cerības pamazām izplēnēja, un, daudziem trimdiniekiem izcelojot uz mītnes zemēm gandrīz visos pasaules kontinentos, doma reiz atgriezties brīvajā Latvijā pamazām pārdzima utopijā. Citiem vārdiem, pirmajā periodā šādi organizāciju dibināšanas pasākumi bija vairāk aktuālas, akūtas dabas, vērsti uz noteiktā brīža situāciju, norisēm neilgā laika sprīdī, savukārt 60. gadu mēǵinājumus jau varam uzskatīt par centieniem izveidot pastāvīgas struktūras ar ilgtermiṇa ideju. Vienlaikus šādi centieni apliecina, ka, esot trimdā pat vairākas desmitgades, latvieši un latviešu izcelsmes jūrnieki, kas jau sen lielākoties kugóoja zem svešu valstu karogiem sveštautiešu apkalpju sastāvā, joprojām jutās gana nedroši un sveši ne vien Rietumu tautsaimniecībā, bet arī rietumnieku vidē kopumā (tiesa, gadiem ejot, tas manījās, pateicoties visupirms latviešu asimilācijai mītnes zemju tautās un nācijās).

Jau pašos pirmajos trimdas gados Eiropā novērojami atsevišķ mēgéninājumi "brīvajā pasaulē" palikušajiem latviešu jūrniekiem radīt zināmu ekonomiski institucionālu aizmuguri, proti - radīt jūrnieku pārstāvības organizācijas, tā veicinot pirmkārt latviešu darba meklējumus nozarē. 1945. gada 18. februārī dibinātajā Latviešu apvienībā Zviedrijā, kas darbojās gan latviskās kultūras laukā, gan tautiešu 
saimniecisko interešu aizstāvības virzienā, līdztekus atsevišķai Lauksaimniecības sekcijai tika izveidota īpaša Jūrniecības sekcija (tajā ietilpa arī zvejnieki) ievērojamā tālbraucēja kapteiņa un daudzu latviešu bēg̣̣u laivu vadītāja Voldemāra Jurjaka (1914-1988) vadībā. ${ }^{35}$ Šāds apvienības organizatoru solis - īpašas Jūrniecības sekcijas izveide -, domājams, demonstrē, pirmkārt, to, ka vismaz Zviedrijā un vismaz šīs organizācijas dibinātāju - redzamu sava laika sabiedrisko darbinieku - ieskatos jūrniecība bija nozīmīga latviskās tautsaimniecības nozare (kaut vai trimdā palikušo darbinieku profesionālā spektra ziṇā), kā arī, otrkārt, to, ka problēmas, kas vajāja baltiešu jūrniekus un kas, protams, arī veicināja nepieciešamību pēc šãdas pārstāvības, dūrās acīs ne tikai pašiem jūrniekiem. Acīmredzamo uzskatu par jūrniecības nozares nozīmību organizācijas iekšējās politikas kontekstā tikai stiprināja fakts, ka pirmajā apvienības darbības gadā to vadīja jau minētais ievērojamais sabiedriskais darbinieks J. Zalcmanis kvēls jūrniecības lietu entuziasts, viens no starpkaru Latvijas laika ievērojamākajiem kuĝ̣ipašniekiem un augsts valsts ierēdnis ar jūrniecību saistītās struktūrās. ${ }^{36}$ Latviešu apvienības statūti paredzēja juridiski pārstāvēt latviešu profesionālās kopas, sniegt palīdzību darba meklējumos svešajā mītnes zemē (tam tika izveidots īpašs Darba apgādes un informācijas birojs), rūpēties par nozares darbinieku izglīiības kāpināšanu. ${ }^{37}$ Katrs latviešu jūrnieks, kas vēēējās palīdzību darba meklējumos, tika aicināts iesūtīt biedrībai anketu, norādot pašreizējo dzīvesvietu un aprakstot līdzšinējās gaitas jūrniecībā (nozares izglītība, līdz šim kug̣u apkalpēs veiktie pienākumi un ieņemtie amati, kuğošanas stāžs). ${ }^{38}$

Tomēr jau pašā sākumā organizācijas darbībā bija vērojami uzkrītoši trūkumi galvenokārt darbu organizēšanā. Pusgadu pēc organizācijas nodibināšanas viens no tās dibinātājiem kādā periodiskā izdevumā zobojās, ka teju vissliktāk darbojoties tieši Jūrniecības sekcija:

"Sekcijas vaditäjs pirms mēneša pazudis pat apvienībā vina adresi neviens nezin. Laivas krievini aizveduši. ${ }^{39}$ Darbs zvejniekiem un jūrniekiem nav sagādāts." 40

Jau nākamajā mēnesī, 1945. gada septembrī, latviešu laikraksti slavēja sekcijas panākumus, nodrošinot un nostiprinot Latvijas zvejnieku tiesības zvejot Zviedrijas teritoriālajos ūden,os; ${ }^{41}$ sasniegumu temps - galvu reibinošs. (Trūkst ziṇu par organizācijas panākumiem tālbraucēju jūrnieku lietās.)

Latviešu apvienības Zviedrijā un līdz ar to arī tās Jūrniecības sekcijas darbība apsīka 50. gados - salīdzinot ar līdzīgām organizācijām citās mītnes zemēs, tas neškiet ilgs mūžs.

Gandrīz vienlaik ar tikko apskatīto struktūru Zviedrijā līdzīga latviešu jūrnieku pārstāvība tika organizēta arī DP nometnēs Vācijā. 1945. gada rudenī tā dēvētajā Latviešu aprūpības centrālbirojā Lībekā tika sasaukta "latviešu jūrnieku organizācijas sapulce" ar tālbraucēju kapteini Dagobertu Freidenfeldu un kugu radiotelegrāfistu J. Gaṇgi kā "jūrnieku lietu kārtošanas” pilnvarotajiem priekšgalā. Visi latviešu jūrnieki Vācijā tika aicināti iesūtīt sapulces organizatoriem ziņas par savu līdzšinējo un pašreizējo darbību nozarē (papildus citiem biogrāfiskajiem datiem, tostarp zin̄ām par izglītību, kuru nepieciešamība tika īpaši akcentēta). ${ }^{42}$ Diemžēl trūkst ziṇu par šīs akcijas tālāko norisi, panākumiem un nozīmi, bet skaidrs, ka tās loma bija nospēlēta līdz 1949.-1950. gadam - DP nometnēs izmitināto latviešu tālākizceḷošanas brīdim.

Šo jūrnieku pārstāvības organizāciju galvenais darbības mērḳis tātad bija nodrošināt latviešu jūrniekiem pastāvīgu, mūsdienu terminolog̣ijā runājot, arī gana 
konkurētspējīgu darbu savā nozarē. Līdzīgā virzienā darbojās Baltiešu jūrskola Flensburgā, Vācijā, kuras vadība, īpaši tālbraucējs kapteinis Pauls Neimanis (1884-1966), ne vien rūpējās par Baltijas tautu jaunekḷu izglìtošanu jūrlietās, bet arī lūkoja nodrošināt absolventiem darbu apgūtajā nozarē.

Nākamā skaidri dokumentētā epizode, kas vēstī par biedrošanās un kooperācijas centieniem latviešu trimdas jūrnieku saimē, seko vien 1960. gadā: tā ir divu latviešu jūrnieku nesekmīgā ierosme kopā ar Latvijas sūtniecību Vašingtonā izveidot vispasaules latviešu jūrnieku pārstāvību.

Pirmais konkrētais impulss šai ierosmei bija latviešu jūrnieka Raimonda Mūrnie$\mathrm{ka}^{43}$ nedienas ar vīzas saņemšanu, lai izkāptu krastā ASV, jo, kaut arī lieta atrisinājās veiksmīgi, tā jūrasbraucēju vidē aktualizēja, domājams, laiku pa laikam paklusām apspriesto vajadzību veidot latviešu jūrnieku pārstāvību. Tālāko iniciatīvu uzṇēmās pats R. Mūrnieks un vina komandas biedrs - zviedru motorkuǵa Sunrise stūrmanis Erhards Zariņš, kurš bija iepazinies ar R. Mūrnieka vēstulēm Latvijas sūtniecībai Vašingtonā. Vēstulē Latvijas sūtniecībai Vašingtonā 1960. gada 1. septembrī R. Mūrnieks ierosināja sūtniecībai izveidot latviešu jūrnieku pārstāvju tīklu - amatpersonu grupu - vai vismaz izveidot posteni vienam pārstāvim jeb padomdevējam, "kas pārstāvettu [latviešu] jūrnieku lietas visā pasaulē" un "pie kura [...] varētu griezties, ja būtu grūtibas jeb vēlētos dabūt kādu informāciju par lietām, kas tieši nav mūsu sūtniecìbu uzdevumā un par kurām varbūt arī mūsu sūtniecībām nav ziñu". ${ }^{44}$ Savu nodomu konkretizējot, R. Mūrnieks tālāk raksta, ka jūrniekiem īpaši nepieciešams būtu starpnieks ar dažādu valstu vietējiem dienestiem un organizācijām - ierēdnis, kas varētu palīdzēt latviešu jūrniekiem "uzñemt sakarus ar arodbiedrībām, ievācot ziņas par darba iespējamībām, emigrācijas iestāžu nostāju un tā tālāk". Vienlaikus vēstules autors izteica pārdomas, ka, iespējams, drīzāk kaitīga būtu šāda pārstāvja iecelšana katrā valstī un lielākajā ostas pilsētā atseviški, jo pastāvot risks, ka to latviešu jūrnieks izmantotu negodprātīgi, nododoties personīgām baudām un vājībām: "[...] tad gadìtos diezgan bieži arī tādi jūrnieki, kas, savu naudu nodzēruši, apmeklētu mūsu pārstāvi, lai varētu dabūt vēl vairāk naudas priekš dzeršanas". Toties svarīgi būtu, lai šāds pārstāvis vai pārstāvji vismaz reizi vai divas reizes gadā informētu latviešu jūrniecības saimi par nozīmīgākajām perioda aktualitātēm..$^{45}$

Ierosmes autora minētie pārstāvniecības iemesli ir jau minētās problēmas ar arodbiedrībām, imigrācijas dienestiem, jūrnieku neuzticība un pašu institūciju iedragātā palāivība Latvijas pārstāvniecībām (gan objektīvu, gan subjektīvu apsvērumu dēḷ), kā arī skepse par to, vai citu valstu un starptautiskās struktūras bez latviešu interešu cienījama un oficiāla pārstāvja iedziḷināsies un efektīvi palīdzēs jūrniekam no mazas, nezināmas un pasaulē izsvaidītas nācijas. Vienlaikus R. Mūrnieks norāda, ka sūtniecību Vašingtonā vērtē gana augstu un ka viņš nevarētu iedomāties labāku institūciju, kuras paspārnē varētu darboties iecerētais pārstāvis vai plašāka pārstāvniecība. Jūrnieks arī iesaka izveidot šādu posteni sabiedriskā kārtā, uz entuziasma pamata:

"Nebūtu jau nozīme, vai tas būtu dāma vai kungs. Galvenais, [lai viņš] pats personigi bez atalgojuma vēlētos palìdzēt mūsu jūrniekiem." 46

Vēl konkrētākus priekšlikumus vispasaules latviešu jūrnieku "autorizēta pārstāvja jeb padomdevēja” iecelšanai sniedza R. Mūrnieka cīnuubiedrs E. Zariņš vēstulē sūtniecībai 1960. gada 8. septembrī. Daḷēji iebilstot savam cīņubiedram, viņš norādīja, ka noteikti izveidojams pārstāvju tīkls un ka pārstāvis nepieciešams katrā lielākā ostas 
pilsētā pasaulē. Paredzēdams sūtniecības atrunāšanos ar resursu trūkumu, E. Zariņš piemetināja, ka citu pārstāvības struktūru (arodbiedrību) trūkuma apstākḷ̆os paḷāvība uz sūtniecības iesaisti esot latviešu jūrnieku pēdējā cerība ilgās pēc pārstāvības un ka diezin vai sūtniecības izveidota pārstāvju tīkla darbinieki būtu sevišķi noslogoti un tādēḷ īpaši atalgojami - varbūt vienam otram tādam pārstāvim nāktos uzrakstīt pa kādai vēstulei gadā. "Tas pārstāvja amats būtu vairāk kā goda amats, kas tomēr dažreiz priekš viena otra no mūsu jūrniekiem būtu kā glābšanas rinkisis sliktos apstākḷos.” Pēc E. Zariņa domām, centrālā pārstāvja funkcijas būtu jāpilda kādai amatpersonai, kas cieši saistìta vai nu ar Latvijas sūtniecību Vašingtonā, vai sūtniecību Londonā kā divām galvenajām un uzticamākajām Latvijas diplomātiskajām pārstāvniecībām. ${ }^{47}$

Lai arī sūtniecība Vašingtonā principā atbalstīja R. Mūrnieka un E. Zariņa ierosmi, tomēr nekāda praktiska rīcība nesekoja, jo, kā savā atbildes vēstulē 21. septembrī norādīja sūtniecības padomnieks Anatols Dinbergs, tas neesot sūtniecības spēkos viena galvenā iemesla dēḷ: latviešu jūrnieki esot pasaulē pārāk izklīdināti, izkaisīti un nodarbināti zem dažādu valstu karogiem, un diezin vai "viens cilvēks, iecelts attiecīgā postenī, no kāda centra, vienalga, vai tāds centrs atrastos šini krastā, Eiropā vai kur citur" varētu ko līdzēt. Kā rezumēja A. Dinbergs, ja neatkarīgās Latvijas laikā, kad jūrnieku Latvijas pilsoṇu skaits pasaules jūrās (pateicoties regulārajām pārvadājumu līnijām) tomēr esot bijis daudz ievērojamāks nekā pēc valsts okupācijas, neesot bijusi īsta vajadzība pēc šādas jūrnieku pārstāvības, tad tagad šādas struktūras izveide liekoties gluži neiespējama - vienīgā izeja esot jūrnieku mēgeinājumi kārtot problēmas, tāpat kā iepriekš sazinoties ar Latvijas Republikas pārstāvniecībām attiecīgajās zemēs, lai arī dažādas problēmas un likstas latviešu jūrniekus droši vien vajāšot kā vajājušas. ${ }^{48}$
Šis praktiskas dabas atteikums un problēmas, ar ko tas pamatots, nebūt nemudināja R. Mūrnieku nedz saraut attiecības ar šo Latvijas pārstāvniecību, nedz mest plinti krūmos: tā paša gada oktobrī R. Mūrnieks sūtniecībai ziņoja, ka kopā ar saviem domubiedriem nodomājis aptaujāt jūrniekus, lai noskaidrotu viņu domas par atsevišķas Latviešu jūrnieku apvienības dibināšanu, kas varētu darboties gan autonomi, gan Daugavas Vanagu organizācijas paspārnē (trūkst ziṇu, vai sākts reāli plānot sadarbību ar Daugavas Vanagu organizāciju). ${ }^{49}$ Līdz 1961. gada 13. janvārim bija noformulēti 12 iecerētās organizācijas darbības uzdevumi, kuru virsmērḳis, kā no tiem izriet, vispārinoši izsakoties, bija latviešu izcelsmes jūrnieku pārstāvība vārda visplašākajā nozīmē, sākot ar dažādu ziṇu uzkrāšanu un beidzot ar reālu palīdzību dzīves apstākḷu sakārtošanā:

1) izveidot mirušo un bojāgājušo latviešu jūrnieku un jūrniecības darbinieku reg̣istru ar īsiem biogrāfiskiem aprakstiem par katru aizgājēju;

2) apkopot ziṇas par bijušās Latvijas kugiem un to gaitām;

3) atsevišķi apkopot ziņas par tiem Latvijas kuǵiem, kuri brauc ar svešiem karogiem, bet kurus vada latviešu kaptein,i;

4) uzņemt sakarus ar rēderiem, kuri būvē jaunus kug̣us un kuri plāno braukt "ar tādu zemju karogiem, kam ìstu jūrnieku nav", un kuriem tālab piedāvājamas latviešu komandas, garantējot, ka Latviešu jūrnieku apvienība spēs sagādāt pilnu latviešu apkalpi;

5) sniegt palīdzību "darba nespējigajiem" jūrniekiem;

6) sniegt palīdzību darba spējīgajiem jūrniekiem iegūt jebkādu darbu nozarē;

7) rosināt jautājumu par jūrnieku kluba atvēršanu;

8) rosināt gadskārtēja informatīva izdevuma - biletena - izdošanu; 
9) sadarboties ar citām organizācijām;

10) vākt datus par latviešu jūrnieku bijušo un pašreizējo stāvokli un grūtībām, lai tās varētu novērst;

11) sadarbībā ar Baznīcu un citu organizāciju pārstāvjiem informēt jūrniekus par tautiešu sarīkojumu apmeklēšanas un pašu tautiešu satikšanas iespējām;

12) uzņemt biedra kārtā arī tos jūrniekus no visām pasaules daḷām, kam ir vai kam ir bijuši "kādi sakari ar jūru un jūrniekiem". ${ }^{50}$

Tomēr par spīti ieceru vērienam un ambīcijām pavisam drīz kḷuva skaidrs, ka šḳēršlı Latviešu jūrnieku apvienības izveidei ir pārlieku daudz. Jau 1960. gada 14. novembra vēstulē Latvijas diplomātiem Vašingtonā R. Mūrnieks žēlojās - lai gan pasaulē esot vairāki simtu latviešu jūrnieku, kas ir vismaz daḷēji aktīvi savā arodā, diezin vai būtu iespējams nodrošināt efektīvu pulcēšanos, proti, sanāksmju norisi: "Mums būtu maz iespēju sadabūt kopā kādā sanāksmē vairāk kā kādus 10." Tiesa, vēl varot cerēt uz bijušajiem jūrniekiem, kas varbūt krietni palielinātu to jūrniecībā ieinteresēto latviešu skaitu, kuri vēlas biedroties. ${ }^{51}$ Tomēr nosaukt visu veidu latviešu jūrniecības darbiniekus par ieinteresētiem Latviešu jūrnieku apvienības izveidē laikam nav iespējams - to pierādīja gan absolūti remdenā reakcija uz R. Mūrnieka paziņojumiem laikrakstos ar aicinājumu iesaistīties jaundibināmās organizācijas darbāa, ${ }^{52}$ gan grūtības pasaulē izkaisītos latviešu jūrniekus uzrunāt personīgi. 1961. gada 2. februārī no Neapoles uz Vašingtonu aizcelıja R. Mūrnieka pēdējā vēstule sūtniecībai, kurā kaismīgais latviešu jūrnieku aizstāvis ne tikai atzīst savu sakāvi, bet pat atvainojas sūtniecībai par savu aizrautību:

"Vispirms vēlos atvainoties par visiem rakstiem, kurus esmu piesūtijis Sūtniecībai, aiznemot Jūsu laiku ar jautājumu par varbūtēju iespējamïbu dibināt Latviešu Jūrnieku
Apvienību. [...] Ir jāatzīstas, ka visas pūles ir bijušas veltigas un par biedrïbas dibināšanu jeb kādu kug̣u sadabūšanu nav ko domāt."

Agrāko ambīciju un pretenziju vietā R. Mūrnieka vēstulē izskan pat šaubas par nu jau apglabātās ieceres lietderīgumu, pat ja tā būtu izdevusies:

"Domāju, ja tikai būtu kāds [latviešiem vairāk vai mazāk garantēts - D. B.] kugis, tad jau jūrnieki sarastos arī bez kādas biedrïbas. [...] Cerēsim, ka kādreiz tiešām redzēsim tādus laikus." ${ }^{53}$

Latviešu kuğotājus trimdā kooperatīvo struktūru izveidē mazliet apsteidza latviešu izcelsmes kugīipašnieki, galvenokārt gādājot tieši par iepriekšminētajām kompensāciju saņemšanas problēmām, kas arī kḷuva par primāro, tiešo pamudinājumu kooperēšanās tieksmei, kuru ārēji spārnoja arī daudz cēlāki nolūki. Te atkal ar labu vārdu piesaucams latviešu kuǵniecības uzṇēmējs un sabiedriskais darbinieks J. Zalcmanis, kuru latviešu rēderu kooperēšanās ieceres sāka nodarbināt jau 1944. gadā. Visupirms J. Zalcmanis, protams, aizstāvēja paša pārstāvētās kompānijas - bijušās Latvijas Kuğniecības sabiedrības - biedru un kuğu līdzīpašnieku intereses, būdams viṇu galvenais pilnvarnieks, ${ }^{54}$ tomēr ātri vien cien̄̄jamā jūrniecības aktīvista darbalauks kḷuva daudz plašāks.

"Tā kā visi [latviešu] kuǵu ìpašnieki un arī l̦audis visās savās lietās pēc atbalsta griežas pie manis kā pie vecākā kuǵu ìpašnieka, kurš arī Latvijas laikā bija galvenais kuǵniecības un tās interešu aizstāvis, būtu vēlams, ka man Jūs, augsti godātais Ministra kungs, pieškirtu kaut kādas, kaut arī minimālas tiesỉbas visas mūsu zemes kuǵniecỉbas lietās saziñā ar sūtni V. Salnajs kungu [...] Saprotams, ka nekad neizlietotu vinas mūsu 
zemes interesēm necienigi, ko, domāju, ar savu ilggadeju sabiedrisko darbu esmu jau pierādījis,"

pie Latvijas sūtṇa Vašingtonā Alfrēda Bīlmaņa 1945. gada sākumā vērsās J. Zalcmanis. A. Bīlmaņa atbilde šim lūgumam pēc kaut kādām pilnvarām, protams, bija noraidoša, aizbildinoties (domājams, pamatoti) ar pašas sūtniecības pilnvaru ierobežojumiem. ${ }^{56}$

Saduroties ar savā mītnes zemē, Zviedrijā, visai ierobežotajām iespējām lietas labā, tā paša 1945. gada 6. novembrī J. Zalcmanis pārcēlās uz dzīvi N̦ujorkā, kur sākās vina aktīvākais darba cēliens. 1951. gadā J. Zalcmanis kḷuva par 1947. gadā Eslingenē dibinātās un 1951. gada maijā uz N̦ujorku pārceltās ${ }^{57}$ Latvijas Saimniecisko darbinieku apvienības (LSDA) priekšsēdētāju, un šis amats viņam l̦āva darboties ar vajadzīgo vērienu. ASV, pateicoties politiskajai nostājai (konsekventi neatzīstot Latvijas inkorporāciju Padomju Savienībā) un superlielvalsts statusam (kura dēḷ tās varēja šādu politisko nostāju atḷauties), bija vislabvēlīgāk noskaņotas Latvijas kuǵu lietās, ciktāl tās attiecās uz atlikušo Latvijas Republikas institūciju un latviešu kug̣īpašnieku interesēm "brīvajā pasaulē". J. Zalcmanis bija pirmais un laikam arī vienīgais, kas ASV nostāju centās izmantot ne tikai atsevišķu kug̣īpašnieku, bet visas latviešu kuǵīpašnieku sabiedrības interesēs, galvenokārt runājot tieši par karalaika fiziskajiem zaudējumiem, ne tik daudz lielvalstu saimnieciskās ekspluatācijas sekām pēckara gados (Lielbritānijas gadījums), uz kurām attiecās citādas juridiskās konsekvences.

1951. gada 15. septembrī saistībā ar šo problēmu J. Zalcmanis vēstulē uzrunāja Latvijas sūtni Vašingtonā Jūliju Feldmanu, aizrādot uz nepieciešamību ASV iesaistīties Latvijai nodarīto karalaika zaudējumu aplēšanā un atlīdzināšanā un uzsverot, ka svarīgi ir ne tikai pašas "Latvijas valsts kā starptautiskas juridiskas personas" ipašumi, bet arī Latvijas pilsoṇu privātie zaudējumi - "kustamā un nekustamā manta, [...] tirdzniecības un rūpniecìbas uzñèmumi u. c.", ${ }^{58}$ tātad arī kugói. Neņemot vērā atsevišķus vairāk vai mazāk veiksmīgus gadījumus, vēl aizvien netrūka tādu kug̣u mantinieku, kas nebija izmantojuši iespēju saņemt atlīdzību par zaudējumiem. Lai situāciju labotu, 1952. gada 21. martā pēc J. Zalcmaņa un citu kuğìpašnieku ierosmes LSDA paspārnē tika izveidota Kuǵniecības sekcija. ${ }^{59}$ Lai arī šīs struktūras darbs neizvērsās, kā cerēts, un tās darbība nebija ilgstoša un produktīva, tā tomēr bija pirmā un vienīgā latviešu kug̣īpašnieku aizstāvības un apvienošanas struktūra, kas vismaz mēgināta izveidot trimdā.

Pirmajā LSDA Kuğniecības sekcijas valdes sastāvā darbojās pats J. Zalcmanis (priekšsēdētājs), tautsaimnieks Dr. Jānis Volmārs (priekšsēdētāja vietnieks), Aleksandrs Šneiders (sekretārs), Pauls Rupners un zvērināts advokāts Pēteris Eglītis (locekḷi). Sekcijas darba mērķis bija "apzināt visus Latvijas kugíniekus, rēderejas un kugiu lìdzīpašniekus, lai kopēji konstatētu savus kara laika zaudējumus un rūpētos par eventuālās atlīdzības vai kompensācijas sañemša$n u$ ", ${ }^{60}$ un tā îstenošanai sekcijas nolikumā minēti trīs konkrēti uzdevumi: 1) apzināt Latvijas kug̣ipašniekus un registrēt to tagadējās adreses; 2) iekārtot arhīvu un uzkrāt statistiku par Latvijas tirdzniecības floti; 3) aplēst kug̣īpašniekiem nodarītos zaudējumus un gadījumos, kur "rastos iespēja kug̛u ìpašniekiem ierosināt zaudējumu atlìdzibu", uzmanīt, "lai šādi ierosinājumi netiktu palaisti garām neizmantoti". ${ }^{61}$ Par savu sūtību Kug̣niecības sekcijas dibinātāji uzskatīja ne tik daudz līdzdalību atsevišķās kuğu kompensāciju lietās, ar tām saistītajos tiesas procesos un sazin̄ā ar attiecīgo valstu valdības iestādēm, cik kopējās kuǵīpašnieku sabiedrības interešu aizstāvību starptautiskos pasākumos, veidojot arī vienotu 
latviešu kug̣īpašnieku kopienas nostāju un veicinot koordinētas rīcības iespējamību izškirīgos gadījumos:

\begin{abstract}
"Kur starptautiskās konferencēs vai karojošām valstìm vedot sarunas par miera ligumiem ies runa par kopējiem kuǵniecïbas jautājumiem, kopējo zaudējumu noteikumiem un kopējo interešu aizstāvēšanu, kopējai vienotai kuǵinieku valodai var būt ļoti svariga nozime." ${ }^{2}$
\end{abstract}

Jau 1945. gada 18. janvāra vēstulē sūtnim A. Bīlmanim J. Zalcmanis uzsvēra, ka par viṇa paša bojāgājušajiem kug̣īpašumiem ASV bankās iesaldētā nauda "dos iespēju domāt par Latvijas kuǵniecības uzbū$v i ",{ }^{63}$ un arī vina vadītās LSDA Kuğniecības sekcijas darbības galvenais virzìtājspēks un idejiskais izejas punkts bija naivās cerības uz neatkarīgās Latvijas iespējamo atjaunotni: tā, pēc J. Zalcmaņa piel̦āvuma, varētu notikt kuru katru brīdi, un šim pavērsienam jābūt gatavai arī kuǵniecības sabiedrībai, kas tādējādi, sadarbojoties ar ASV, varētu veicināt atjaunotās Latvijas kuǵniecības nozares atjaunošanu ${ }^{64}$ (tāpat kā visa LSDA - dot pienesumu Latvijas tautsaimniecības atjaunotnē kopumā) ${ }^{65} \mathrm{Līdz}$ ar to arī konkrēto organizācijas darbības mērku un uzdevumu îstenošana tika uztverta kā pagaidu pasākums: "Latvijas apstāklı šs šos uzdevumus veica $F$ [inansu] $m$ [inistrijas] Jūrniecības departaments, saimnieciskās organizācijas un atsevišķas rēderejas." Un tikai pagaidām, "kamēr radīsies iespēja šos uzdevumus veikt atbrīvotā Latvijā attiecīgām iestādēm, kuğiniekiem jāñem iniciativia savās rokās un jāmēgina aizpildìt šis robs doto iespējamību robežās". ${ }^{66}$

Tomēr, par spīti patētiskajiem mērḳiem, cēlajiem nodomiem, par spīti šo nodomu izziņošanai sabiedriskajā telpā ${ }^{67}$ (cerībā saliedēt zem viena karoga latviešu kug̣īpašniekus visā "brīvajā pasaulē"), veroties latviešu rēderu apvienošanas centienos LSDA paspārnē, jākonstatē, ka pavisam drīz pēc Kuğniecības sekcijas sparīgā pieteikuma un pirmā darbības gada rosmes ${ }^{68}$ sekojis pieklusums tās darbībā, vadībā acīmredzami izvirzoties "sauszemnieku" problēmām (finanšu tirgi, nekustamie ippašumi u. tml.). Turpmākajos gados publicētie LSDA kopējā darba pieminējumi, apskati un raksturojumi, kas minēto tendenci apliecina, ${ }^{69}$ par kuǵniecības lietu kārtošanu itin kā stoiciski klusē, neatklājot arī to, kas īsti šai virzienā paveikts Kug̣niecības sekcijas darba "skaḷākajā" posmā un vai, kopumā raugoties, šīs struktūras darbībai bijusi jelkāda "taustāma” jēga. Fakts, ka sekcija vai kuǵniecība kā darbības virziens, spītējot J. Zalcmanim apvienības vadītāja krēslā, nav pat ar vārdu pieminēta LSDA desmitgadu darbam veltītajā pārskatā, ${ }^{70}$ neko labu neliecina.

Šis LSDA panīkums gan nebūt nenozīmē, piemēram, ka tobrīd - 50. gadu otrajā pusē - vairs nebūtu bijis vajadzības pēc latviešu kug̣īpašnieku kooperēšanās kaut vai tikai kompensāciju lietā vien, jo šĩ cīṇa turpinājās vēl 60. gadu sākumā. Tā bija pirmām kārtām Anglijā, kur, kompensāciju lietas vadīti, nelielās akciju sabiedrībās saliedējās vairāki Lielbritānijā nonākušo tvaikoṇu mantinieki - tvaikoņu akcionāri. Pats zīmīgākais piemērs latviešu kuǵīpašnieku kooperācijai, lai panāktu kompensāciju izmaksu, ir britu nogremdēto kuǵu "Tālvaldis", "Katvaldis" un "Miervaldis" ipašnieku apvienošanās mēgininājums, ko sekmēja tas, ka jau pirms kara visu trīs tvaikonu akcionāri bija savstarpēji saistīti ar noteiktām īpašumu daḷām. Vadošo lomu uzṇēmās trīs tvaikonu akcionāru mantinieks Vilis Tomsons Monreālā, Kanādā, un vairāku kug̣u akcionārs Juris Grīnbergs Edinburgā, Lielbritānijā, pūloties tikt galā ar pārējo akcionāru izkliedētību dažādās valstīs un kontinentos, kas tiklab raisīja zināmas problēmas ar jurisdikciju un dažādu valstu instanču iespējām palīdzēt, kā nespēju šiem akcionāriem sapulcēties koordinētai 
rīcībai nepieciešamās sanāksmēs. ${ }^{71}$ Tāpat zināmas problēmas mēdza radīt atsevišḳu akciju sākotnējo, starpkaru Latvijas laika, ippašnieku atrašanās aiz dzelzs priekškara; piemēram, V. Tomsona māte, kurai piederēja daḷa gimenes uzñēmuma, bija deportēta uz Sibīiju, un radās logiska problēma vai iespējams saṇemt arī vinas, ne tikai tēva Dāvida Tomsona dal̦u. ${ }^{72} 1955$. gadā aktīvi uzsāktās"3 "Katvalža" lietas labvēlìgs iznākums sekoja 1958. gada septembrī, ${ }^{74}$ un tā paša gada oktobrī īpašnieki kopīgi noguldīja jauniegūtās naudas summas N̦ujorkas bankā, ${ }^{75}$ mazliet vēlāk kompensāciju saṇēma arī "Miervalža" akcionāri, bet par "Tālvalža" bojāejas kompensāciju ziṇu pagaidām trūkst.

Kāpēc latviešu jūrnieki trimdā tā arī neizveidoja ilglaicīgas un specializētas arodorganizācijas, vajadzības spiesti, iesaistoties vien mìtnes valstu vai citu nāciju arodstruktūrās? Pirmais un, iespējams, pats svarīgākais klupšanas akmens ir jau minētā latviešu jūrnieku lielā izkliedētība, kas igaun,iem, šķiet, nebija tik izteikta vispirms jau tādēl, ka jūrniecības nozarē darbojas ievērojami lielāks skaits tautiešu, kā arī, iespējams, pateicoties lielajai jūrnieku koncentrācijai dažās pasaules vietās - galvenokārt Zviedrijā, kur atradās abu igauņu jūrnieku arodorganizāciju sēdekḷii. ${ }^{76}$ Vērsdamies pie Latvijas sūtniecības Vašingtonā, R. Mūrnieks pamatoti bažījās:

"Es nedomāju, ka kaut kas iznāktu, ja mēs, jūrnieki, mēginātu atalgot kādu savu pārstāvi. Priekš tā mēs esam par daudz izklaidēti [resp., izkliedēti - D. B.] pa dažādu valstu kugóiem." 77

Tiesa gan, pārdomas raisa vēstules autora vērojums, ka jūrnieki cietuši no pārlieka laika trūkuma, ka viņiem nav bijuši gana "labi apstākļi", lai nodarbotos ar šo problēmu koordinēti; ${ }^{78}$ šḳiet, ka gan laiku, gan līdzekḷus, ja vien būtu bijusi ìsta vēlme pašorganizēties, būtu iespējams sameklēt, jo tobrīd - 60. gados - jau pasaules jūrās sāka parādīties aizvien vairāk labi izglītotu, attiecīgās pavalstniecības ieguvušu un līdz ar to arī labi situētu jūrnieku, no kuriem daḷa, kā zināms, labprāt iesaistījās gan tautiešu, gan mìtnes zemju sabiedriskajā dzīvē, atrazdami tam pietiekami daudz laika. Drīzāk te, iespējams, būtu jārunā par izteiktu noslāņošanos veiksmīgākajos un mazāk veiksmīgajos - ar piebildi, ka veiksmīgākajiem bieži vien pārlieku nerūpēja mazāk veiksmīgo liktenis (vismaz ne tik l,oti, lai veiksmīgie kā nozīmīgi un savās mītnes valstīs, iespējams, gana ietekmīgi spēlētāji atbalstītu to tautasbrāḷ centienus, kam šādas arodstruktūras būtu vairāk nepieciešamas), kā arī, ja tā varētu teikt, viensētnieka savrupība.

Par otru klupšanas akmeni var uzskatīt atbilstošas pieredzes trūkumu - proti, visdrīzāk latviešu un Latvijas jūrniecības darbiniekiem šai ziṇā nebija nekādas vērā ņemamas iepriekšējas pieredzes. Trūkst ziṇu par šādām jūrnieku pašpārstāvniecībām to latviešu jūrnieku aprindās, kas Latviju atstāja līdz Otrajam pasaules karam, ieskaitot laiku līdz neatkarīgās Latvijas Republikas dzimšanai 19. gadsimtā un 20. gadsimta sākumā. Kāpēc tā? Pirmkārt, latvieši, to skaitā jūrnieki, itin bieži, spìtējot grūtībām, spējuši veiksmīgi iekḷauties svešu valstu ekonomiskajā dzīvē, no nacionālo vērtību saglabāšanas viedokḷa - bieži vien pat pārlieku veiksmīgi, ātri vien zaudējot savu latviskās piederības apziṇu (jāsaprot, ka salīdzinājumā ar jūrnieku masveida nonākšanu Rietumos - agrākajos laikposmos izceḷotāji galvenokārt izbrauca vairāk vai mazāk mērḳtiecīgi, apzinoties iespējamās grūtības, ne juku apstākḷlos). Otrkārt, vismaz uz Rietumu vai Latīṇamerikas valstīm šāda latviešu jūrnieku (vai latviešu, kas vēlāk pievērsās jūrniecībai) migrācija nebija ne uz pusi tik masveidīga un daudzskaitlīga, kāda tā bija, sākot ar 
Otro pasaules karu; latviešu jūrnieki, pateicoties jūrskolās labi (jūrniecības virsniecībai atbilstoši) izglìtoto latviešu jaunekḷu "pārprodukcijai", ${ }^{79}$ pārsvarā rada labi atalgotas darbvietas citviet Krievijas impērijā (Odesā u. c.), ārpus tās izceḷojot reti. Arī Latvijā, pat ne Latvijas Republikā 20. gadsimta 20.-30. gados, šādas organizācijas, kas aizstāvētu pasaules jūrās braucošos jūrniekus - valstspiederīgos, nebija, jo par viṇiem sarežğijumu reizēs gādāja diplomātiskās pārstāvniecības - vesels "diplomātisko un konsulāro pārstāvïbu tïkls, kas saskañā ar Latvijas likumiem un pieñemtajām normām kārtoja visus konsulāros jautājumus un kā vienu no pirmajiem - jautājumus un problèmas, kas skar mūsu jūrniekus"; 80 šīs rūpes turpinājās arī pēc Latvijas okupācijas un aneksijas 1940. gadā.

Trimdas periodā, kad trūka jūrlietu arodstruktūru, tieši Latvijas diplomātisko pārstāvniecību loma latviešu un citas etniskās izcelsmes valstspiederīgo interešu aizstāvībā pasaules jūrās daudzos aspektos kḷuva vēl būtiskāka, nereti - izškiroša, jo vairs nebija nedz neatkarīgās valsts Jūrniecības departamenta, nedz kādu citu nozares tautsaimnieciskās pārraudzības institūciju, kas varētu risināt Rietumos nonākušo jūrnieku problēmas. Tagad diplomātiskās un konsulārās pārstāvniecības Rietumos vienlaikus turpināja pildìt savus brīvvalsts gadu pienākumus un aizstāja centrālās nozares struktūras. Grūti pārvērtējams ir Latvijas pārstāvniecību atbalsts latviešu kug̣ippašniekiem mantojumu un kompensāciju lietās, ${ }^{81}$ palīdzība nelaimē nonākušajiem jūrniekiem gan konsulāri (izgādājot vai apstiprinot personas un cel,ošanas dokumentus, ${ }^{82}$ kontaktējoties ar ārvalstu dienestiem), ${ }^{83}$ gan informatīvi (līdzīgi kā starpkaru Latvijas laikā). ${ }^{84}$ Tomēr daudzkārt sūtniecības un konsulāti palīdzēt jūrlietu darboniem nespēja, jo suverēnas valsts apstākḷos pien,emtie Latvijas Republikas likumi strikti ierobežoja diplomātisko un konsulāro pārstāvniecību kompetences un pilnvaras, turklāt ar vairākām valstīm Latvijas Republikai vienkārši nebija diplomātisko vai konsulāro attiecību; tāpat vainīgi savās likstās nereti bija paši jūrnieki, nesakārtojot personas un imigrācijas dokumentus ${ }^{85}$... Protams, šādos gadijumos Latvijas Republikas pārstāvji savas valsts pavalstniekam neko nevarēja līdzēt pat pie vislabākās gribas un visabsurdākajās situācijās, reizēm gan pūloties vismaz uzrunāt attiecīgo valstu atbildīgās struktūras un cerot uz vinu apžēlošanos (sak, mēgénināts nav zaudēts). Taču, pat pastāvot starpvalstu diplomātiskajām attiecībām un citiem formāliem priekšnoteikumiem cerīgam iznākumam, ne vienmēr vienas valsts diplomāti varēja iespaidot citas valsts imigrācijas dienestu rīcību, ${ }^{86}$ un vēl mazāk savas vai kādas citas valsts privātfirmu (tostarp rēdereju) nostāju; ${ }^{87}$ neba vienmēr pārstāvniecības varēja gana operatīvi reaǵêt loti steidzamos gadījumos, piemēram, brīvdienās nedēlas nogalēs. ${ }^{88}$

Dažbrīd jūrnieku arodstruktūru trūkumu trimdā (īpaši tās sākumposmā) kompensēja tautiešu - entuziastu privāta darbība. Proti, tie latviešu jūrniecības darbinieki, kas bija nokḷuvuši vairāk vai mazāk svarīgos postenos, reizumis tomēr palīdzēja iekārtot darbā tautiešus, kam paveicies mazāk un kas saskārušies ne tikai ar šḳēršliem kādas valsts likumdošanā, bet arī, piemēram, ar ārzemju (vietējo) kuǵu kapteinu nevērību pret latviešu jūrnieku, kāda diemžēl pastāvēja, ${ }^{89}$ bet no kuras varēja palīdzēt izvairīties tieši labāk situēto tautasbrāḷu "aizmugure". Savus tautiešus aktīvi atbalstīja, piemēram, kāds jūrnieks K. Ošiņš N̦ujorkā, kurš darbvietas uz kugiem jau 40. gadu beigās līdzējis dabūt ne vienam vien latviešu jūrniekam; ${ }^{90}$ ticis pie turības, K. Ošinš̌ šajā lielpilsētā atvēris pat savu restorānu, kas kḷuvis par latviešu jūrnieku iemīlotu pulcēšanās un neoficiālu problēmjautājumu risināšanas vietu. 
Daudz laba šai virzienā darījis arī kapteinis Augusts Galdiñ̌s, darbodamies kā ostas inspektors Sanfrancisko. ${ }^{91}$ Reizēm savus tautiešus - ne tikai jūrniekus - loti atbalstīja arī latviešu tautības kuğu kapteiņi bēgḷu nometñu laikā, kad darbu nebija viegli atrast daudziem latviešiem, uzn,emoties zināmu risku un pieṇemot darbā uz kug̣a pat tādus DP nometniekus, kas iepriekš ar jūru nav bijuši saistīti. Šeit pieminams, piemēram, tvaikona "Venta" kapteinis Krišjānis Sleja - viņš sava tvaikon,a jauno apkalpi 40. gadu nogalē sastādīja tikai no DP nometniekiem - Mirvikas nometnes iemītniekiem, jaunākā matroža vietu dodams nometnes grāmatu tirgotājam Miķelsonam (kā mazs kuriozs jāpiezīmē tas, ka savā rangā gan krietni nācās kristies bijušajam Jūrniecības departamenta direktoram G. Krūmiņam, kuram K. Sleja ierādīja kuğa stjuarta vietu...). ${ }^{92}$

\section{$* * *$}

Lai gan trimdā pēc Otrā pasaules kara nonākušie un palikušie latviešu jūrniecības darbinieki, pretēji igauṇu jūrlietu aprindām un pretēji citu tautsaimniecības nozaru darboṇiem pašu klaida latviešu lokā, neizveidoja noturīgas arodstruktūras, kas pārstāvētu viṇus mītnes valstu tautsaimniecībā un ḷautu apspriest savas nozares problēmas trimdas un, iespējams, kādreiz atjaunojamās Latvijas valsts tautsaimniecības kontekstā (kā to aktīvi piekopa citas baltiešu trimdinieku arodstruktūras), rakstā aplūkotie mēǵinājumi tomēr šḳiet gana interesanta epizode latviešu trimdas un tautsaimniecības norišu pagātnē. Šì epizode lieku reizi gan apliecina jūrnieka aroda un arī klaidā nonākuša jūrniecības uzṇēmēja vai sabiedriskā darbinieka darbības specifiku un daudzās grūtības, kas piederēja pie šīs specifikas, gan, iespējams, atsedz zināmas latviskās mentalitātes šķautnes, kuru vidū izceḷas zināma savrupība, ko nespēja pārvarēt pat dedzīga atsevišḳu entuziastu darbība. Izteikta trimdas sabiedrības tendence, kas viegli izskaidrojama ar tautiešu integrāciju mītnes valstu tautsaimniecībā un vienlaik savas nacionālās apziņas un kultūras saglabāšanas tieksmi, ir tā, ka saimnieciski kooperatīvā saliedēšanās nav salīdzināma ar kultūras izkopsmes organizācijām, kas trimdā ilgstoši bijušas l,oti plašas un spēcīgas. Tā 1966. gadā arī jūrniecības darbinieki iekḷāvās šajā tendencē, izveidodami sabiedrisko organizāciju - Latvijas jūrniecības vēstures arhīvu, kas Latvijas un latviešu jūrlietu pagātnes lappušu izpētē sekmīgi apvienoja jūrniecības vēstures entuziastus (gan jūrniekus, gan citus interesentus, arī no vēstures profesoru un vācbaltiešu vidus); līdzīgi saviem domubiedriem, šîs organizācijas galvenais rosinātājs tālbraucējs kapteinis Arvalds Kalniņš (1917-2006) Kārdifā, Lielbritānijā, tobrīd augsta ranga kug̣inieks būdams, protams, jau bija gana labi situēts un varēja atḷauties pilnībā nodoties intelektuāli sabiedriskajām aktivitātēm.

\section{ATSAUCES UN SKAIDROJUMI}

${ }^{1}$ Plašāk par to sk. turpmākajā tekstā.

${ }^{2}$ Displaced Persons - "pārvietotās personas" (angḷu val.) - jēdziens, kas šajā gadījumā attiecināms uz baltiešu bēgliem pēckara Vācijā un Austrijā.

${ }^{3}$ Pirmām kārtām - vācu okupācijas perioda.

${ }^{4}$ RAIMUNDS ČAKs. Latviešu preses biedrības darbs ārpus Latvijas. In: HERONIMS TICHOvsKis. Latviešu trimdas desmit gadi. Toronto 1954, 260. lpp. 
${ }^{5}$ Piem.: Latviešu Ārstu un Zobārstu Apvienības valdes sekretāra T. M. Vītola vēstule Latvijas sūtnim A. Spekkem, 14.01.1957. Latvijas Nacionālā arhīva Latvijas Valsts vēstures arhīvs, Rìga (turpmāk - LNA LVVA), 293-1-1454, 105. lp.

${ }^{6}$ Piem.: Latviešu Mežkopju un Meža darbinieku savienības pārstāvja A. Kipena vēstule Latvijas sūtniecībai Vašingtonā, 25.04.1951. Ibidem, 13. lp.

${ }^{7}$ Piem.: Latviešu Juristu Apvienības valdes locekḷa A. Ūdra vēstule Latvijas sūtniecībai Vašingtonā, 14.02.1952. Ibidem, 66. lp.

${ }^{8}$ Piem.: Latviešu inženieru biedrības ASV valdes priekšsēža R. Pāvela vēstule Latvijas sūtnim Jūlijam Feldmanam, 04.04.1953. Ibidem, 74. lp.

${ }^{9}$ Piem.: Latvijas dzelceḷnieku centra sekretāra V. Krieviña vēstule Latvijas sūtnim J. Feldmanam, 27.12.1953. Ibidem, 78. 1p.

${ }^{10}$ H. M. Nodibināta latviešu kooperācijas apvienība. In: Latvija, 10.06.1947., 1. lpp.

${ }^{11}$ Par trimdas profesionālajām apvienībām plašāk sk. daudzajās trimdas preses publikācijās, kā arī, piem.: Latvijas sūtniecības Vašingtonā padomnieka Anatola Dinberga vēstule jūrniekam Raimondam Mūrniekam, 27.10.1960. LNA LVVA, 293-1-1946, 12. lp.; DAGMĀRA TALCE-NIEDRE. Zeme un Tauta. Rakstu krājums. N,ujorka 1955 u. c.

${ }^{12}$ Igauṇu jūrnieki stājas darbā. In: Latvju Vārds, 18.08.1945., 1. lpp. Tiesa, igauṇu jūrnieku, domājams, vismaz Zviedrijā bija krietni vairāk nekā latviešu jūrnieku, turklāt igauṇu jūrniekiem atšḳirībā no latviešiem daudzos gadījumos palīdzējusi iesaistîšanās Zviedrijas kuǵniecības struktūrās.

${ }^{13}$ Igauṇu jūrnieku arodbiedrība brīvajā pasaulē. In: Latvija Amerikā, 20.04.1955., 3. lpp.

${ }^{14}$ Nogrimis igauņu kugóis. In: Latvija Amerikā, 15.02.1958., 8. lpp.

${ }^{15}$ Darba iespējas uz igauṇu kuớiem. In: Londonas Avīze, 12.02.1960., 3. lpp.

${ }^{16}$ Sīkāk sk.: V. O. "Latvji, brauciet jūriņā...": Kā amerikanizējies latviešu rēderis piemānīja mūsu jūrniekus. In: Latvija, 17.12.1949., 2. lpp.

${ }^{17}$ Latviešu jūrnieki trimdā, īpaši tie, kuriem pēc padomju varas priekšstatiem nebija visai "tīra" vai "pareiza" pagātne Latvijā un kuri to lieliski apzinājās, izteikti baidījās no šādām situācijām. R. Mūrnieka vēstule Latvijas sūtniecībai Vašingtonā, 01.09.1960. LNA LVVA, 293-1-1946, 6. lp.; Jūrnieka Ludviga Kiiploka vēstule Latvijas sūtnim Vašingtonā J. Feldmanam, 26.08.1950. Ibidem, 293-1-1943, 106. lp.; IMANTS BALODIs. Dažādās vietās un laikos. Nepublicētas atminnas [datorraksts; divi tā eksemplāri glabājas Rīgas vēstures un kuğniecības muzeja Latvijas kuǵniecỉbas vēstures nodaḷas (turpmāk - RVKM LKVN) arhīvā un Kalnciema pagasta muzeja zinātniskajā arhīvā]. Kanāda, ap 1998, 18. lp.

${ }^{18}$ Sk., piem.: Jūrnieka Boḷeslava Senkeviča vēstule Latvijas sūtnim Vašingtonā par ASV ierēdṇu politisko piesardzību un aizdomīgumu, 01.01.1953. LNA LVVA, 293-1-1943, 115. 1p.; Kapteiņa Kārḷa Kirmušakas vēstule Latvijas sūtniecībai Vašingtonā par Latīṇamerikas valstu krasta dienestu aizdomīgo attieksmi pret latviešiem kā maskētiem komunistu pārstāvjiem, 23.02.1955. Ibidem, 123. lp. u. c.

${ }^{19}$ Sīkāk par šīm problēmām sk.: DĀVIS BEITLERS. Latviešu jūrniecība trimdā 1944-1987: kugói, jūrnieki, organizācijas. Maǵistra darbs. Rīga 2017, 112.-130. lp.

${ }^{20}$ Par grūtībām, kas piemeklēja latviešu jūrniekus trimdā, sk. arī: DĀvIS BEITLERS. Latviešu jūrnieks tālos ceḷos. In: ANITA FrEIBERGA (red.). Latvijas Jūrniecības gadagrāmata 2017. Rìga 2018, 427.-433. lpp.

${ }^{21}$ Sīkāk sk.: DĀVIS BEITLERS. Ieskats Graudu gimenes rēderejas darbībā trimdā. In: Latvijas Universitātes Žurnāls. Vēsture 2017, Nr. 4, 112.-125. lpp.

${ }^{22}$ Izcils sabiedrisks darbinieks mūžībā. Miris Jānis Zalcmanis. In: Londonas Avīze, 10.09.1971., 6. lpp.

${ }^{23}$ MANFRĒDS ZICHMANIS. Brāḷi Zēbergi: personības, burinieki, tvaikoṇi. Toronto 1986, 20. lpp. 
${ }^{24}$ Militāri saimniecisku apsvērumu dēl gan ASV, gan Lielbritānija Otrā pasaules kara laikā ar īpašu likumdošanas aktu palīdzību pārṇēma savā rīcībā to ūden̦os nonākušos Latvijas pavalstnieku kuğus, juridiski vairumā gadījumu saglabājot kuğu formālās îpašumtiesības, kas paredzēja īpašuma atdošanu pēc karalaika ekspluatācijas vai kompensācijas izmaksu kuǵa bojāejas gadījumā.

${ }^{25}$ Sk. turpmākajā tekstā.

${ }^{26}$ Darbojās no 1945. līdz 1950. gadam, latviešu bēgḷu aprūpē iesaistoties 1946. gadā un papildinot Apvienoto Nāciju Palīdzības un atjaunošanas pārvaldes darbību (UNNRA - United Relief and Rehabilitation Administration).

${ }^{27}$ Konstantīns Ozolin̦š. "Mazā Latvija” un latviešu dzīve Vācijā. In: TichovsKis, Latviešu trimdas desmit gadi, 307.-308. lpp.

${ }^{28}$ OL̦EgS GoNČARovs. Patiesība par jūrniekiem. In: Latvija, 28.05.1949., 2. lpp.

${ }^{29}$ PAUls NeIMANis. Norvēgei negribēja latviešus. In: Latvija, 15.06.1949., 2. lpp.

${ }^{30}$ R. Mūrnieka vēstule Latvijas sūtniecībai Vašingtonā, 01.09.1960. LNA LVVA, 293-1-1946, 5. lp. (R. Mūrnieks raksta: "Ka mūsu jūrnieki ir diezgan slikti informēti, apliecina tas fakts, ka Karacas ostas pilsētin̄ā La Guaira ir bijusi šad un tad apmeklēta no mūsu jūrniekiem, jo tur pienāk diezgan daudz kuğu, bet Latvijas pārstāvis Venecuēlā, mācītājs Gulbja kungs, saka, ka mēs esam tie vienigie jūrnieki, par kuriem vinam esot zināms, jo neviens cits nekad nav apmeklējis nedz Baznīcu, nedz latviešu koloniju. Varu piebilst, ka latviešu kolonija Karakās pret iebraucējiem ir l̦oti viesmilìga.")

${ }^{31}$ R. Mūrnieka vēstule Latvijas sūtniecībai Vašingtonā, 14.10.1960. Ibidem, 10. lp.

${ }^{32}$ R. Mūrnieka vēstule Latvijas sūtniecībai Vašingtonā, 01.09.1960. Ibidem, 5. lp.

${ }^{33}$ Sk., piem.: Mūsu jūrnieki svešumā. In: Latvija Amerikā, 14.07.1954., 2. lpp.

${ }^{34}$ Protams, ne jau visas minētās problēmas šādas struktūras spētu atrisināt tieši, uz līdzenas vietas, tomēr tas varētu būt solis uz priekšu.

${ }^{35}$ KĀRLIS SiLĀBrAms. Latviešu zvejnieku rūpes. In: Latvju Vārds, 24.03.1945., 2. lpp.

36 JĀNIS ZALCMANIS. Ne apkarošanos, bet darbu latviešu labā. In: Latvju Vārds, 24.03.1945., 2. lpp.

${ }^{37}$ Zviedru laikraksti par Latviešu apvienību Zviedrijā. In: Latvju Vārds, 31.03.1945., 1. lpp.

${ }^{38}$ Latviešu apvienība Zviedrijā. Ziṇojumi. In: Latvju Vārds, 24.03.1945., 2. lpp.

39 Šeit, protams, ir runa par Latvijas valsts un pavalstnieku peldlīdzekḷiem, ko Skandināvijas valstis, ieskaitot Zviedriju, tūlīt pēc kara izdevušas Padomju Savienībai.

${ }^{40}$ Zem bundžas vāka: Latviešu apvienība Zviedrijā. In: Bundža. Malēniešu driḳējums gara uzfrišināšanai, 01.09.1945., 2. lpp.

${ }^{41}$ Latviešu Apvienības pagājušās vasaras darbs. In: Latvju Vārds, 11.09.1946., 4. lpp.

${ }^{42}$ Latviešu jūrnieki organizējas. In: Dzimtene, 10.10.1945., 1. lpp.

${ }^{43}$ Ir zināms, ka R. Mūrnieks dzimis 1925. gada 17. maijā Bebrenē un ap divdesmit gadu nobraucis uz Latvijas un vēlāk Zviedrijas flotes tvaikoņiem kā samērā zema ranga jūrnieks - pārsvarā matrozis. Viṇam vēl 1960. gadā Latvijā bijuši piederīgie - māte gados (R. Mūrnieka vēstule Latvijas sūtniecībai Vašingtonā, 25.03.1960. LNA LVVA, 293-1-1946, 1. lp.).

${ }^{44}$ R. Mūrnieka vēstule Latvijas sūtniecībai Vašingtonā, 01.09.1960. Ibidem, 1., 4. lp.

${ }^{45}$ Ibidem, 4. 1p.

${ }^{46}$ Ibidem, 5. lp.

${ }^{47}$ E. Zariña vēstule sūtniecībai Vašingtonā, 08.09.1960. Ibidem, 7. lp.

${ }^{48}$ Latvijas sūtniecības Vašingtonā padomnieka A. Dinberga vēstule R. Mūrniekam, 21.09.1960. Ibidem, 9. 1p.

${ }^{49}$ R. Mūrnieka vēstule Latvijas sūtniecībai Vašingtonā, 14.10.1960. Ibidem, 10. 1p.

${ }^{50}$ R. Mūrnieka sniegtās ziņas Latvijas sūtniecībai Vašingtonā par Latviešu Jūrnieku Apvienības koncepciju, 13.01.1961. Ibidem, 27. lp. 
${ }^{51}$ R. Mūrnieka vēstule Latvijas sūtniecībai Vašingtonā, 14.11.1960. LNA LVVA, 293-1-1946, 16. lp.

${ }^{52}$ Sk., piem.: Jūrnieku ievērībai [par Latviešu Jūrnieku Apvienības dibināšanas ieceri, aicinājums latviešu jūrniekiem izteikties un iesaistīties]. In: Londonas Avīze, 28.10.1960., 6. lpp. un 04.11.1960., 7 lpp.; Austrālijas Latvietis, 12.11.1960., 2. lpp.; Jūrnieku un jūrnieku labvēḷu ievērībai. In: Laiks, 26.10.1960., 8. lpp. u. c.

${ }^{53}$ R. Mūrnieka vēstule Latvijas sūtniecībai Vašingtonā, 02.02.1961. LNA LVVA, 293-1-1946, 28. lp.

${ }^{54}$ Kuğìipašnieka A. Bērziṇa vēstule Latvijas sūtnim Vašingtonā A. Bīlmanim, 23.10.1945. Ibidem, 293-21-1931, 14. lp.

55 J. Zalcmaņa vēstule Latvijas sūtnim Vašingtonā A. Bīlmanim, 21.01.1945. Ibidem, 8. lp.

${ }^{56}$ Latvijas sūtṇa Vašingtonā A. Bīlmaņa vēstule J. Zalcmanim, 17.02.1945. Ibidem, 9.-10. lp.

57 Latvijas Saimniecisko Darbinieku Apvienības (LSDA) 20.04.1951. sanāksmes Ṇujorkā protokola noraksts. Ibidem, 293-1-1454, 10. lp.

${ }^{58}$ LSDA priekšsēdētāja J. Zalcmaņa vēstule Latvijas sūtnim Vašingtonā J. Feldmanam, 15.11.1951. Ibidem, 8. lp.

59 LSDA Kug̣niecības sekcijas uzaicinājuma [ikvienam atlīdzības u. c. interesentam] paraugs (1952. gada marts), nosūtīts Latvijas sūtniecībai Vašingtonā. Ibidem, 9. lp.

${ }^{60}$ Kuǵniecības sekcija. In: Laiks, 23.04.1952., 5. lpp.

${ }^{61}$ Visu trīs mērḳu sasniegšanai jeb uzdevumu îstenošanai Kuğniecības sekcija sāka apkopot datus par atsevišşāam rēderejām un to ìpašuma - kug̣u - likteni.

${ }^{62}$ LSDA Kuğniecības sekcijas uzaicinājuma paraugs (LSDA Kuğniecības sekcijas uzaicinājuma paraugs, 1952. gada pavasaris). LNA LVVA, 293-1-1454, 9. lp.

${ }^{63}$ J. Zalcmaṇa vēstule Latvijas sūtnim Vašingtonā A. Bīlmanim, 08.01.1945. Ibidem, 293-1-1931, 5. lp.

64 J. Zalcmaņa vēstule sūtnim J. Feldmanam, 23.05.1951. Ibidem, 293-1-1454, 9., 12. lp.

${ }^{65}$ Saimnieciski pētījumi Latvijas atjaunošanai. In: Laiks, 03.05.1952., 3. lpp.

${ }^{66}$ LSDA Kuğniecības sekcijas uzaicinājuma paraugs, 1951. LNA LVVA, 293-1-1454, 9. lp.

${ }^{67}$ Sk. paziņojumus laikrakstos, piem., Latvija Amerikā, 07.05.1952. u. c.

68 1953. gada marta beigās prese vēl apgalvoja, ka "kuǵniecìbas sekcija, amatnieku un namziṇu kopa [...] darbojas ar labiem panākumiem". Sk.: Jaunas sekcijas Saimniecisko darbinieku apvienībai. In: Laiks, 28.03.1953., 6. lpp. Par Kuǵniecības sekcijas darbīgumu sk. arī: Saimnieciski pētījumi Latvijas atjaunošanai. In: Laiks, 03.05.1952., 3. lpp.

${ }^{69}$ Sk., piem.: Aizrādījums. In: Laiks, 13.01.1954., 6. lpp.; Saimniecisko darbinieku apvienība. In: Londonas Avīze, 17.06.1955., 2. lpp.; Saimniecisko darbinieku sanāksme. In: Londonas Avīze, 03.05.1957., 2. lpp. u. c.

${ }^{70}$ Saimniecisko darbinieku apvienība. In: Londonas Avīze, 30.03.1956., 2. lpp.

${ }^{71}$ Kapteiṇa Vị̣a Tomsona vēstule Jurim Grīnbergam Edinburgā [kserokopija], 17.10.1958. Pielikums Arvīda Kārkliņa apceres "Latvijas tirdzniecības flote" manuskripta II sējumam, 78. lp. RVKM LKVN zinātniskais arhīvs.

${ }^{72}$ V. Tomsona vēstule A. Kārkliṇai N̦ujorkā, 31.01.1956. Ibidem, 84. lp.

${ }^{73}$ Tautsaimnieka Jāṇa Volmāra vēstule V. Tomsonam, 23.06.1955. Ibidem, 44. lp.

${ }^{74} \mathrm{~V}$. Tomsona vēstule J. Grīnbergam, 01.10.1958. Ibidem, 82. 1p.

${ }^{75}$ Advokāta Eižena Kerno vēstule V. Tomsonam, 15.10.1958. Ibidem, 82., 91. lp.

${ }^{76}$ Igauṇu kuǵniecība brīvajā pasaulē. In: Latvija Amerikā, 01.02.1963., 8. lpp.

77 R. Mūrnieka vēstule sūtniecībai Vašingtonā, 01.09.1960. LNA LVVA, 293-1-1946, 5. lp. Mūrnieka izteikumu apstiprina arī visnotal ticamā piebilde, ka viņš personīgi veselu gadu neesot sastapis nevienu no mūsu jūrniekiem, izṇemot stūrmani E. Zariṇu no viṇa paša pārstāvētās kuğa komandas. 
${ }^{78}$ R. Mūrnieka vēstule sūtniecībai Vašingtonā, 01.09.1960. LNA LVVA, 293-1-1946, 5. lp.

${ }^{79}$ Lìdz 19. gs. beigām vien vienpadsmit t. s. Valdemāra jūrskolas absolvēja ap 3000 tâlbraucēju kapteiṇu, tālbraucēju stūrmaņu un tuvbraucēju stūrmaṇu.

${ }^{80}$ Latvijas sūtniecības Vašingtonā padomnieka A. Dinberga vēstule R. Mūrniekam, 21.11.1960. LNA LVVA, 293-1-1946, 9. 1p.

81 Jurista Kārla Kḷaviṇa (Mehiko) vēstule A. Dinbergam ar lūgumu noskaidrot ziṇas par ASV bankās palikušiem konkrētu kuǵīpašnieku līdzekḷiem, 30.08.1962. Ibidem, 293-1-1935, 1. lp.; informatīvā palīdzība tika sniegta arī igauniem - sk.: Latvijas sūtniecības Vašingtonā sarakste ar Igaunijas generālkonsulu J. Kaivu (Kaiv) par Igaunijas kug̣a Koidula likteni, 1949. Ibidem, 293-1-1934.

${ }^{82}$ Latvijas sūtṇa Vašingtonā A. Bīlmaṇa vēstule sūtniecības vicekonsulam A. Dinbergam, 17.12.1940. Ibidem, 293-4-225, 9. 1p.

${ }^{83}$ Sk., piem., materiālus par jūrnieku pasēm 1946.-1954. gadā. Ibidem, 293-1-1944.

${ }^{84}$ Piem.: LNA LVVA, 2570-9-6 (Latvijas Republikas Ārlietu ministrijas likumi, ziņojumi un apkārtraksti jūrniecības lietās 1939.-1940. gadā); ibidem, 2570-9-63 (materiāli par Latvijas jūrniecības stāvokli 1939.-1940. gadā); ibidem, 2575-7-2645 (Latvijas sūtniecības Marseḷā (Parīzē) palīdzība Latvijas kug̣u avāriju lietās 1940. gadā); ibidem, 2575-7-2647 (Latvijas sūtniecības Marsel̦ā (Parīzē) palīdzība latviešu jūrnieku lietās 1938.-1940. gadā) u. c.

${ }^{85}$ Latvijas sūtniecības Vašingtonā padomnieka A. Dinberga vēstule R. Mūrniekam, 27.10.1960. Ibidem, 293-1-1946, 12. lp.

${ }^{86}$ Ar šādu apstākli bija jāsaskaras, piemēram, latviešu jūrniekam Albertam Einam, kurš 1945. gadā bija nonācis imigrācijas dienestu apcietinājumā Kanādā, vērsdamies pēc palīdzības Latvijas sūtniecībā Vašingtonā, kura varēja vien ieteikt griezties vai nu pie Latvijas sūtniecības Londonā, kurai ar Kanādu vismaz formāli un vēsturiski bija lielāka juridiskā saikne, vai arī pie Latvijas kuğus operējošām ağentūrām vai latviešu kaptein̦iem. Sk.: A. Eina sarakste ar Latvijas sūtniecību Vašingtonā 1945. gada februārī. Ibidem, 293-1-1943, 4.-5. lp.

${ }^{87}$ Piem.: Latvijas sūtniecības Vašingtonā sekretāra A. Dinberga vēstule jūrniekam L. Kịplokam saistībā ar viņa atlaišanu no ASV kompānijas Steel Worker kuğa, 31.08.1950. Ibidem, 105. lp.

${ }^{88}$ R. Mūrnieka sarakste ar Latvijas sūtniecību Vašingtonā 1960.-1961. gadā. Ibidem, 10., 12., 16. lp.

${ }^{89}$ Piem.: Latviešu jūrnieka Vladimira Brika vēstule Latvijas konsulātam N̦ujorkā, Elisa sala, 23.10.1946. Ibidem, 10.-12. lp.

${ }^{90}$ JĀNIS VESTFĀLIS. "Ķegums" brauc ar Latvijas karogu: latviešu jūrnieki pasaules ūdeņos un svešās zemēs. In: Latvija, 12.03.1948., 3. lpp.

${ }^{91}$ OsvaldS AKMENTiN̦š. Ciemos pie mūsu jūrnieku audzinātāja. In: Tēvzeme, 13.03.1948., 4. lpp.

${ }^{92}$ VDN. Pasaules jūrās vēl brauc 10 Latvijas kuğu. In: Latvija, 19.10.1949., 2. lpp.

\section{SUMMARY}

The Latvians in exile after the Second World War quite actively established various social organizations, which included associations of employees and clerks of various sectors of the economy - engineers, doctors, foresters, railwaymen etc.; these associations organized global meetings and congresses, discussed the topical problems of the industry and the restoration of the Latvian economy at the moment when Latvia would regain its independence. However, Latvian maritime workers - representing historically one of the most important sectors of the Latvian economy and also represented in exile by professionals - were not successful in creating professional groups or professional organizations for the exchange of ideas, like trade unions or forums. 
In principle, there were numerous reasons for Latvian seafarers and shipping employees to cooperate in exile. Seamen faced many difficulties in finding job at shipping companies in their home countries, resistance of local trade unions in the West to employ Latvian seamen, problems with immigration services and authorities from different countries and coast guard structures during commercial voyages with ships, etc. Latvian shipowners' activities in exhile also did not enjoy permanent success, being hampered by international economic tendencies and economic policy of some Western countries (for example, the reluctance of Western countries' governments to pay compensation to Latvian shipowners for ships, which were wrecked when sailing under the flags of Western countries, especially the United Kingdom). Of course, not all of these problems could be solved directly by seafarers' trade organizations and similar cooperative structures (including those uniting shipowners), yet it would give the workers and entrepreneurs of maritime field a sense of legal unity and solidarity.

Meanwhile, another Baltic nation - Estonians - successfully created their own seafarers' associations. They founded several unions uniting a large number of Estonian sailors and actively collaborating with the Estonian shipowners in exile. Occasionally, Estonian sailors' associations helped Latvian sailors to find work on Estonian ships, although this apparently should have been done by similar organizations founded by Latvians themselves and collaborating with the Latvian shipowners in exile.

The shortage of Latvian seafarers' and shipowners' associations and cooperative structures in exile partly compensated the work of post-war refugee supply organizations (mainly - International Refugee Organisation, who tried to place Latvian refugee seamen to work on ships), a few private enthusiasts - Latvians, who had obtained some weight in the Western maritime services in exile, and especially - the diplomatic missions of the Republic of Latvia in the West (mostly - Latvian Embassy in Washington DC, which had an outstanding role in Latvian maritime history in exile and during World War II). 